\title{
ハイブリッド制御に基づく二足歩行ロボットの 障害物跨ぎ越え*
}

櫛田 大輔 $\dagger$. 竹森 史暁 $^{\dagger} \cdot$ 北村 章 ${ }^{\dagger}$

\section{Stepping Over Excess of Obstacle for Biped Robot Based on Hybrid Control*}

\author{
Daisuke Kushida $^{\dagger}$, Fumiaki TAKemori ${ }^{\dagger}$ and Akira Kitamura ${ }^{\dagger}$
}

\begin{abstract}
In this research, it paid attention to that system of stepping over the obstacle by biped robot same as HDS, where continuous and discrete event exist together. And it was made to return to optimal control problem after it had expressed by MLDS in consideration of various constraint conditions. In a general ZMP control, because it is necessary to consider the constraint condition and the optimality separately, it complicates by coexistence of two or more control theories. On the other hand, the stepping over excess of the obstacle with biped robot based on the hybrid control can systematically achieve optimum control because it can treat them in the same way. In this paper, it was shown that the stepping over excess of the obstacle with biped robot was able to return in optimal control problem, and the effect was confirmed by the simulation work.
\end{abstract}

\section{1. まえがき}

二足歩行ロボットは人間の歩行動作と同等なものを実 現できるため，現在のインフラをそのまま使用できるメ リットがある。そのため, より人間に近い動作を目指し た歩行の研究が近年盛んに行われている. 現在の二足歩 行ロボットの歩行に関する研究では, 歩行中のロボット にかかる重力と慣性力によるモーメントがゼロになる点 を床面上に投影したZMP（Zero Moment Point）を安 定領域の内部に限定する方法が主として用いられてい る [1-3]. しかしながら, ZMP 制御は二足歩行ロボット を安定して歩行させるための工学的な解決策の一つであ り，人間の歩行原理や人間に近い動作との関連性はあま りない.

つぎに，二足歩行ロボットが歩行する際，遊脚と支持 脚が歩行ごとに切り替わるため, 離散的な現象が生じて いることに着目する。 また，階段状のステップや障害物 の跨ぎ越えの場合においても，その前後において障害物 と遊脚のつま先（もしくはかかと）が干渉しないような 拘束条件が状況に応じて離散的に切り替わっている。こ

* 原稿受付 2006 年 1 月 5 日

$\dagger$ 鳥取大学 工学部 Faculty of Engineering, Tottori University; 4-101 Koyamachominami, Tottori city, Tottori 680-8552, JAPAN

Key Words: hybrid dynamical system, hybrid control, MLDS, biped robot, stride.
のような観点から考えると，二足歩行ロボットの歩行動 作は，連続的な事象と離散的な事象が混在している系と してとらえることができる。

一方，連続事象と離散事象の混在した系として Hybrid Dynamical System（以下 HDS）がある [4,5]. HDS は MLDS (Mixed Logical Dyanamical Systems) という 表現方法によって論理变数を含んだ線形不等式として定 式化することができ $[6-8]$, 最適制御問題として州着さ せることが可能であることが知られている。

そこで本研究では, 二足歩行ロボットの歩行動作を HDS としてとらえるとともに, 人間の行動決定手法が周 辺環境を拘束条件とした最適制御手法と類似しているこ とを考慮して，二足歩行ロボットの歩行動作を運動方程 式や拘束条件を含んだ最適制御問題として扱う。その際, 平地の歩行に関しては, 拘束条件が現在主流の ZMP の みとなることから，同様な結果となることが予想される ため, 最短経路による障害物跨ぎ越えという動作を対象 としてとらえることとする。

\section{2. ハイブリッド制御による跨ぎ越え}

2.1 跨ぎ越え動作とハイブリッドシステム 前進二足歩行による障害物の跨ぎ越えは Fig. 1 に示す ような連続事象と離散事象が混在したものとして表現す ることができる. Fig. 1 は mode $1 \sim \operatorname{mode} 4$ に分割され ているが，それぞれの mode 内では二足歩行ロボットの 


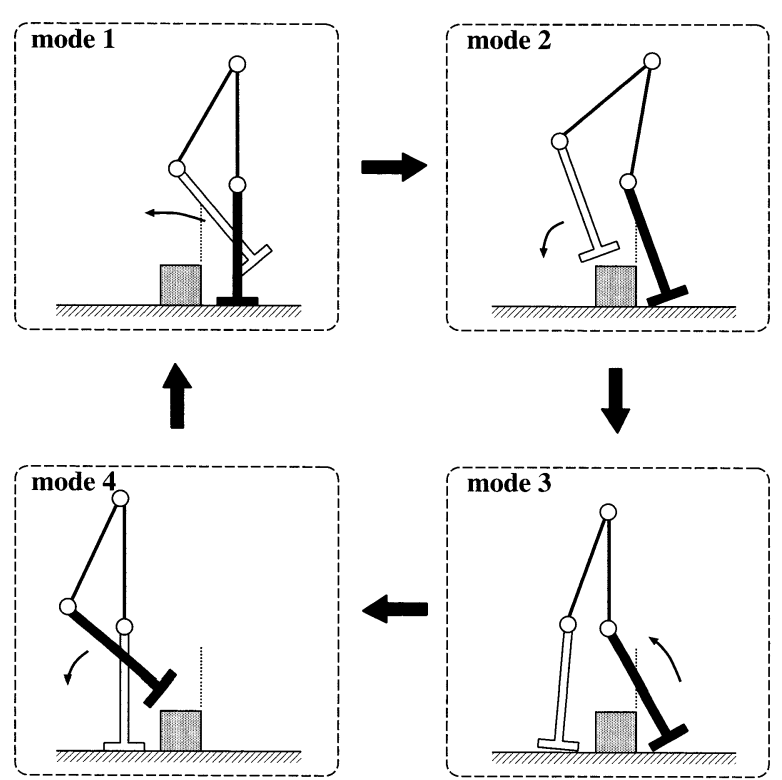

Fig. 1 Automaton of biped robot's stride

連続的な動作を示している。 それに対し，各 mode 間で は，障害物を跨ぎ越える前後や支持脚と遊脚の切替えと いった離散的に表現される動作を示している. mode 1 から mode 2 への遷移は, 白抜で表現されている脚（遊 脚）が点線で表される障害物の境界線を越えた際に行わ れる. mode 2 から mode 3 への遷移は遊脚か障害物を越 えて地面に着地した際に行われる。このとき, 白抜で表 現されている脚は遊脚から支持脚, 黒塗りで表現されて いる脚は支持脚から遊脚へと機能が切り替わる. mode 3 から mode 4 , mode 4 から mode 1 への遷移は新たな 遊脚である黒塗りの脚によって同様に行われる。このよ うに，跨ぎ越え動作は mode 1 から mode 4 を遷移する ことで実現される.しかし，実際には modeの切替えに 伴なう拘束条件のほかに, ロボットが転倒しないための 重心位置の拘束条件, 障害物を跨き越えるための拘束条 件, 機械的にロボットの動作速度を制限する拘束条件な どが存在する。これら拘束条件も，二足歩行ロボットと 周辺環境との関係に伴なって切替えが必要となる。次節 よりこれらの拘束条件を導いていく，なお，本論文では 前進跨ぎ越え動作を対象としており, 後進に関しては考 えないものとする.また, 動作速度がモー夕の定格速度 に対して中低速となるような一般的な歩行を考える.

\section{2 跨ぎ越え実現のための拘束条件}

\subsection{1 モード切替えの拘束条件}

Fig. 2 に mode 1 から mode 2 , mode 2 から mode 3 へ と切り替わる様子を示している. (a)より mode 1 が mode 2 に切り替わる直前の状態は, ロボットのつま先 $Q$ は障害 物の右上 $O$ よりも右側に存在している必要がある。また, (b)より mode 2 から mode 3 に切り替わる直前の状態 は，口ボットのかかと $P$ は地面近傍の高さを示している $z_{\epsilon}\left(z_{\epsilon}>0\right)$ よりも上部に存在している必要がある.これ らを式で表現すると以下のような拘束条件が導かれる.

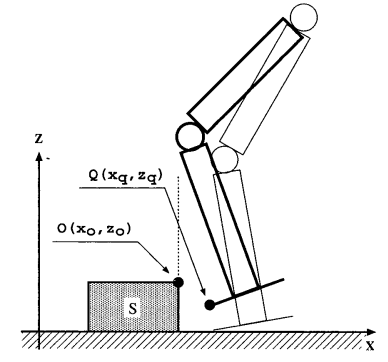

(a) Mode 1 to 2

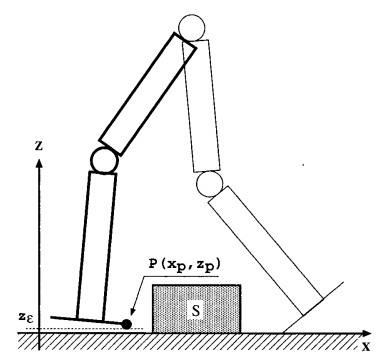

(b) Mode 2 to 3
Fig. 2 Condition of mode switching

$$
\begin{aligned}
& x_{q} \geq x_{o} \\
& z_{p} \geq z_{\epsilon}
\end{aligned}
$$

つまり, Fig. 2 の太線で表現されている遊脚に関して (1)，(2) 式の条件を両方満たしている場合は mode 1 , mode 1 の状態において，(1) 式の条件を満たさなくなっ た場合は mode 2, mode 2 の状態において，(2) 式の条 件を満たさなくなった場合は mode 3 (このとき遊脚は 細線で表現される脚へ切り替わり, 同時に (1), (2) 式は 満たされることとなる), mode 3 の状態において, (1) 式の条件を満たさなくなった場合は mode 4 となる.

\subsection{2 重心位置の拘束条件}

二足歩行ロボットが転倒しないための手法として一般 的に静歩行があるが，今回は人間と同じ歩行である動歩 行を考えていく. 動歩行は重心位置を足底接地面より外 しながら歩行を行う手法であり, 今回は動歩行の中でも 受動歩行という倒れ込みを利用した歩行形態を対象とし た.この受動歩行では, 重心位置が両脚のつま先とかか との間に入っていれば転倒することはないため,これを 拘束条件として式で表現すると

$$
\begin{aligned}
& {\left[x_{q}^{s} \leq x_{q}^{l}\right] \Rightarrow\left[x_{q}^{s} \leq G_{x} \leq x_{p}^{l}\right]} \\
& {\left[x_{q}^{s}>x_{q}^{l}\right] \Rightarrow\left[x_{q}^{l} \leq G_{x} \leq x_{p}^{s}\right]}
\end{aligned}
$$

となる。ここで $G_{x}$ は二足歩行ロボットの重心をX 軸座 標に投影した值, $x_{q}^{s}, x_{p}^{s}$ は遊脚のつま先とかかとの位置 を $\mathrm{X}$ 軸座標に投影した值, $x_{q}^{l}, x_{p}^{l}$ は支持脚のつま先とか かとの位置をX 軸座標に投影した值である。また，遊脚 と支持脚は前節で説明した modeの状態によって切り替 わるものとする.

一般的に歩行を行う際には, 加速度の実現性を考慮す るため ZMP が支持脚の足裏に収まる必要があるが，今 回は加速度の小さい中低速動作を対象としているため, 特にZMPは考慮せずともその条件は満足されると仮定 し, 重心位置のみの拘束条件とした。

\section{2 .3 障害物の拘束条件}

つぎに，障害物を跨ぎ越える際の拘束条件について考 えていく. Fig. 3 に遊脚が障害物を跨ぎ越える際の様子 を示している. (a) は障害物を跨ぎ越える前の様子であ 
るが，この後，障害物と遊脚のつま先との接触を避けな がら，遊脚を障害物の上部へと運ぶ必要がある。遊脚つ ま先 $Q$ が障害物の右上 $O$ より右側にある場合は， $Q$ の 高さは地面より高ければ問題はないが，Qが $O$ より左側 にある場合，遊脚のすね部分は $O$ の上部になければなら ない.この拘束条件を式で表現すると

$$
\begin{aligned}
& {\left[x_{q} \geq x_{o}\right] \Rightarrow\left[z_{q} \geq 0\right]} \\
& {\left[x_{q}<x_{o}\right] \Rightarrow\left[g\left(x_{f}, z_{f}, \phi\right) \geq 0\right]}
\end{aligned}
$$

となる。ただし

$$
g\left(x_{f}, z_{f}, \phi\right)=\left(x_{o}-x_{f}\right) \sin \phi-\left(z_{o}-z_{f}\right) \cos \phi+\frac{r}{2}
$$

である．また，(b) は障害物を跨ぎ越え終える前の様子 であるが，この後，障害物と遊脚かかととの接触を避け ながら，遊脚を障害物の先へと着地させる必要がある. 遊脚かかと $P$ が障害物の左上 $R$ より右側にある場合は, $P$ の高さは $R$ より高ければ問題はない. しかし， $P$ が $R$ より左側にある場合，遊脚を障害物の左側に垂直に着地 させるために，遊脚のすね部分は $R$ の上部になければな らない.このような拘束条件を式で表現すると

$$
\begin{aligned}
& {\left[x_{p} \geq x_{r}\right] \Rightarrow\left[z_{p} \geq z_{r}\right]} \\
& {\left[x_{p}<x_{r}\right] \Rightarrow\left[h\left(x_{f}, z_{f}, \phi\right) \geq 0\right]}
\end{aligned}
$$

となる。ただし

$$
h\left(x_{f}, z_{f}, \phi\right)=\left(x_{r}-x_{f}\right) \sin \phi-\left(z_{r}-z_{f}\right) \cos \phi-\frac{r}{2}
$$
である。

\subsection{4 動作速度の拘束条件}

これまでは物理的な拘束に関して考慮してきたが，実 際にロボットを駆動させるモータにおいてもトルクや速 度に関する拘束があるのが一般的である。いま，Fig. 3 における二足歩行ロボットの膝関節 $F$ を基にして，その 位置と角度で表現された運動方程式を

$$
x(k+1)=A x(k)+B u(k)
$$

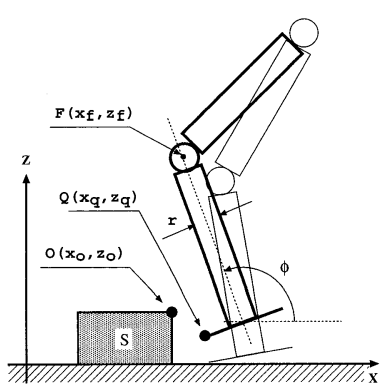

(a) Before over the obstacle

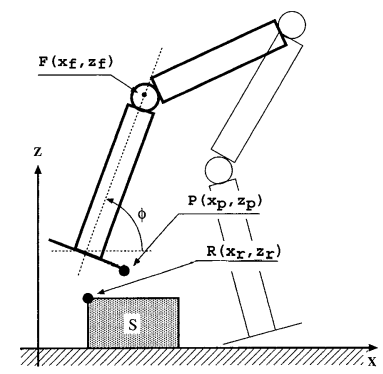

(b) After over the obstacle
Fig. 3 Constraint based on relationship between obstacle and leg position

$$
\left\{\begin{array}{l}
x(k)=\left[x_{f}(k), z_{f}(k), \phi(k)\right]^{\mathrm{T}} \\
u(k)=\left[u_{x f}(k), u_{z f}(k), u_{\phi}(k)\right]^{\mathrm{T}} \\
A=\left(1-\frac{\Delta t}{\tau}\right) I_{3}, \quad B=\left(\frac{\Delta t}{\tau}\right) I_{3}
\end{array}\right.
$$

という 1 次系で表現する。ここで, $x_{f}(k), z_{f}(k)$ はそれ ぞれロボット膝関節 $F$ の X 座標, $\mathrm{Z}$ 座標であり, $\phi(k)$ は膝関節と X 軸との角度である（Fig. 3 参照）。また， $u_{x f}(k), u_{z f}(k), u_{\phi}(k)$ は $x_{f}(k), z_{f}(k), \phi(k)$ に対する 制御入力， $\tau$ および $\Delta t$ はそれぞれ時定数とサンプリン グ時間間隔， $I_{3}$ は $3 \times 3$ の単位行列である。一般的には 詳細な非線形モデルを用いることが望ましいが，二足歩 行ロボットの各リンクが独立線形モデルとして扱える中 低速動作の範囲内であることを考慮すると，(9) 式でも 十分代用可能である. ロボットのトルクや速度に関する 拘束を，サンプリング時間間隔ごとの入力偏差に制限を かけることで表現すると拘束条件は

$$
|u(k)-u(k-1)| \leq\left[M_{x f}, M_{z f}, M_{\phi}\right]^{\mathrm{T}}
$$

として表される。ここで, $M_{x f}, M_{z f}, M_{\phi}$ はそれぞれ膝 関節座標の X 軸方向への最大移動可能量, Z 軸方向への 最大移動可能量, 膝関節下脚の最大回転可能量である. この拘束条件は二足歩行ロボットを駆動するために用い られているすべてのモータに依存するものであり，その ため各モータの拘束条件は(10) 式ですべて表現すること ができているととらえることができる．実際のモー夕の 駆動は $(10)$ 式を満たすような $u(k)$ が求まった後, それ を実現するモータの目標速度を逆算し，それに従うよう PID制御を行うことで実現する。

\subsection{MLDS による定式化}

これまで二足歩行ロボットが障害物の跨ぎ越えを行う にあたり，必要となる拘束条件を導いてきた。いま，二 足歩行ロボットで障害物を跨ぎ越える動作をMLDSで 表現するために, 拘束条件 $(1) \sim(8)$ 式の各要素に対して 論理変数 $\delta$ を

$$
\begin{aligned}
{\left[x_{q} \geq x_{o}\right] } & \Leftrightarrow\left[\delta_{1}=1\right] \\
{\left[z_{p} \geq z_{\epsilon}\right] } & \Leftrightarrow\left[\delta_{2}=1\right] \\
{\left[x_{q}^{s} \leq x_{p}^{l}\right] } & \Leftrightarrow\left[\delta_{3}=1\right] \\
{\left[x_{q}^{l} \leq G_{x} \leq x_{p}^{s}\right] } & \Leftrightarrow\left[\delta_{4}=1\right] \\
{\left[x_{q}^{s} \leq G_{x} \leq x_{p}^{l}\right] } & \Leftrightarrow\left[\delta_{5}=1\right] \\
{\left[x_{q} \geq x_{o}\right] } & \Leftrightarrow\left[\delta_{6}=1\right] \\
{\left[z_{q} \geq 0\right] } & \Leftrightarrow\left[\delta_{7}=1\right] \\
{\left[g\left(x_{f}, z_{f}, \phi\right) \geq 0\right] } & \Leftrightarrow\left[\delta_{8}=1\right] \\
{\left[x_{p} \geq x_{r}\right] } & \Leftrightarrow\left[\delta_{9}=1\right] \\
{\left[z_{p} \geq z_{r}\right] } & \Leftrightarrow\left[\delta_{10}=1\right] \\
{\left[h\left(x_{f}, z_{f}, \phi\right) \geq 0\right] } & \Leftrightarrow\left[\delta_{11}=1\right]
\end{aligned}
$$

のように割り当てる。すると， $(1) \sim(8)$ 式は

$$
\delta_{1}=1
$$




$$
\begin{aligned}
& \delta_{2}=1 \\
& {\left[\delta_{3}=1\right] \Rightarrow\left[\delta_{4}=1\right]} \\
& {\left[\delta_{3}=0\right] \Rightarrow\left[\delta_{5}=1\right]} \\
& {\left[\delta_{6}=1\right] \Rightarrow\left[\delta_{7}=1\right]} \\
& {\left[\delta_{6}=0\right] \Rightarrow\left[\delta_{8}=1\right]} \\
& {\left[\delta_{9}=1\right] \Rightarrow\left[\delta_{10}=1\right]} \\
& {\left[\delta_{9}=0\right] \Rightarrow\left[\delta_{11}=1\right]}
\end{aligned}
$$

のような論理式に書き直すことができる，つぎに，この ような論理式を不等式へ変換していく。いま，(22), (23) 式を例に取ると (11), (12) 式を基にして

$$
\begin{array}{r}
\left\{\begin{array}{r}
x_{q}-\left(M_{x}-x_{o}+\epsilon\right) \delta_{1}-x_{o}+\epsilon \\
-x_{q}+\left(x_{o}-m_{x}\right) \delta_{1}+m_{x} \leq 0
\end{array}\right. \\
\left\{\begin{array}{r}
z_{p}-\left(M_{z}-z_{\epsilon}+\epsilon\right) \delta_{2}-z_{\epsilon}+\epsilon \\
-z_{p}+\left(z_{\epsilon}-m_{z}\right) \delta_{2}+m_{z} \leq 0
\end{array}\right.
\end{array}
$$

として，不等式へ変換することができる。ただし

$$
\left\{\begin{array}{l}
m_{x} \leq x_{q} \leq M_{x} \\
m_{z} \leq z_{p} \leq M_{z} \\
\epsilon>0
\end{array}\right.
$$

であり， $\epsilon>0$ は十分に小さな正の定数， $m_{x}, M_{x}$ はそれ ぞれ $x_{q}$ の取り得る最小值と最大值, $m_{z}, M_{z}$ はそれぞれ $z_{p}$ の取り得る最小值と最大值である. 同様にして $(24)$ (29) 式に関しても等価な不等式に変換すると

$$
\begin{aligned}
\delta_{3}-\delta_{4} & \leq 0 \\
1-\delta_{3}-\delta_{5} & \leq 0 \\
\delta_{6}-\delta_{7} & \leq 0 \\
1-\delta_{6}-\delta_{8} & \leq 0 \\
\delta_{9}-\delta_{10} & \leq 0 \\
1-\delta_{9}-\delta_{11} & \leq 0
\end{aligned}
$$

となる. 以上のように二足歩行ロボットの跨ぎ越え動作 をMLDS 形式で記述することができる。

\section{4 最適制御問題}

ハイブリッドシステムをMLDS として記述すること で，ある種の最適性の指標のもと，制御方策を決定でき ることが知られている $[8]$. 本論文では評価関数を

$$
\begin{aligned}
J=\sum_{k=0}^{K-1}\left[\left\{\frac{x_{f}(k)-x^{d}}{W_{x}}\right\}^{2}\right. & +\left\{\frac{z_{f}(k)-z^{d}}{W_{z}}\right\}^{2} \\
& \left.+\left\{\frac{\phi(k)-\phi^{d}}{W_{\phi}}\right\}^{2}\right]
\end{aligned}
$$

として設定した。ここで, $x^{d}, z^{d}, \phi^{d}$ は次ステップでの $x_{f}(k), z_{f}(k), \phi(k)$ の目標位置であり, $W_{x}, W_{z}, W_{\phi}$ は $(38)$ 式右辺の各項の重みである. 重みの意味は各項が評価值 $J$ に及ぼす比率として解釈されたい. 本最適制御問題で は, 時刻 $k$ ごとに $(30) \sim(37)$ 式の拘束約条件を満たし,
$(38)$ 式の評価関数を最小にする $u_{x f}(k), u_{z f}(k), u_{\phi}(k)$ を求める. これは, 実変数と離散変数を決定変数とする ことから混合整数計画問題を解くことで最適解を得るこ とができる。

\section{3. 跨ぎ越えシミュレーション}

前章で説明した混合整数計画問題を解き, 歩行動作のシ ミュレーションを行った. 問題の解法にはMS-Excel2003 に付属するソルバーアドインを用いた。ソルバーアドイ ンは拘束条件を満足しながら評価式を最小化する機能を 有しているが,リアルタイムにて最適化計算を行うこと はできない. そのため, 今回はシミュレーションによる 検証のみに留まっているが, 本手法の本質を損なうもの ではない. 本論文で提案している手法は, 現在の脚位置 に基づく拘束条件を満足しながら, 次ステップにて到達 すべき目標脚位置へ動作するための制御入力を評価関 数を最小にするよう逐次求めるものである.これは一般 的にフィードバック形式になるが，上述したようにリア ルタイム計算を行うことができないため, ロボットの挙 動をあらかじめ想定してフィードフォワード形式にてシ ミュレーションを行った. 対象とする二足歩行ロボット は下半身のみであり, 全長 $0.9[\mathrm{~m}]$, 股関節から滕関節ま てでが $0.45[\mathrm{~m}]$, 膝関節から着地面までが $0.45[\mathrm{~m}]$, また, つま先からかかとの距離は $0.18[\mathrm{~m}]$ である。ロボットの 質量は (9) 式に含めて考えるため, 特に定める必要はな いが，各リンクの重心位置はリンクの中心にあるものと 仮定する. その他のシミュレーション条件はTable 1 に 示す.また，シミュレーション結果を Figs. 4〜 7 に示し ている。

Fig. 4 は，二足歩行ロボットの重心位置の推移と拘束 条件との関係, Fig. 5 は遊脚と障害物の位置関係と拘 束条件との関係, Fig. 6 は二足歩行ロボットへの制御入 力と制御入力の拘束条件との関係, Fig. 7 はシミュレー ション結果を視覚化したものを示している.

Fig. 4 では, 実線が重心位置, 点線が重心位置の上限, 破線が重心位置の下限となっているが, 重心位置は常に 上下限内に入っており，(3)，(4) 式で表されている拘束 条件を満たしていることがわかる.

Fig. 5(a-1)，(a-2)は，Fig. 3の太線で表されている脚 が遊脚である場合の (5) (8) 式で表現される拘束条件の

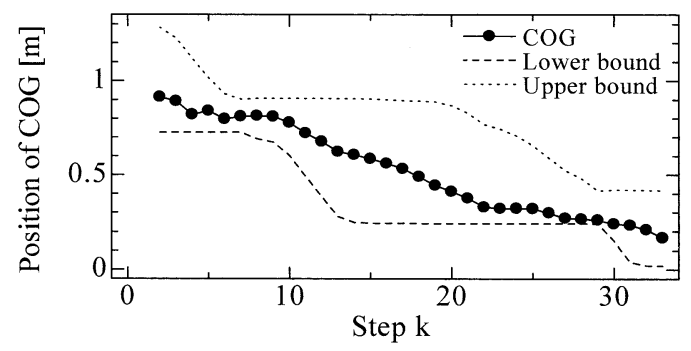

Fig. 4 Results of the stride of biped robot under COG constraints 


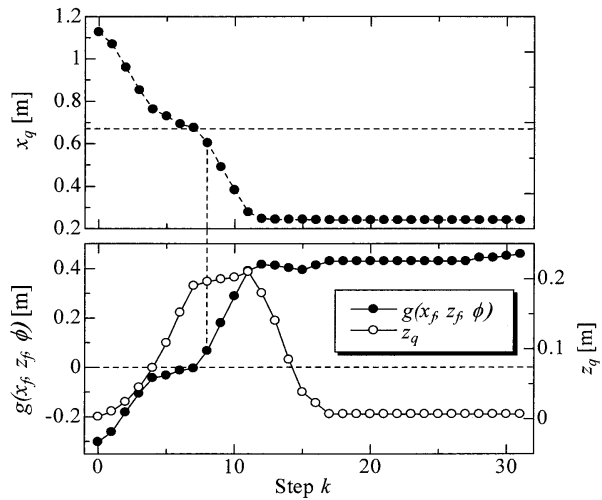

(a-1) Before over (bold line leg)

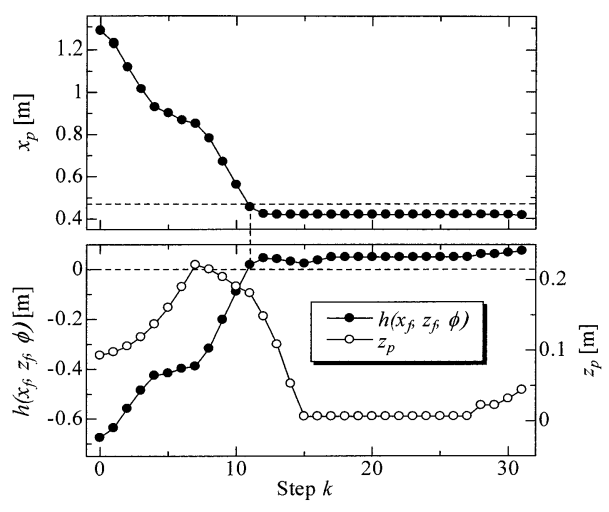

(a-2) After over (bold line leg)

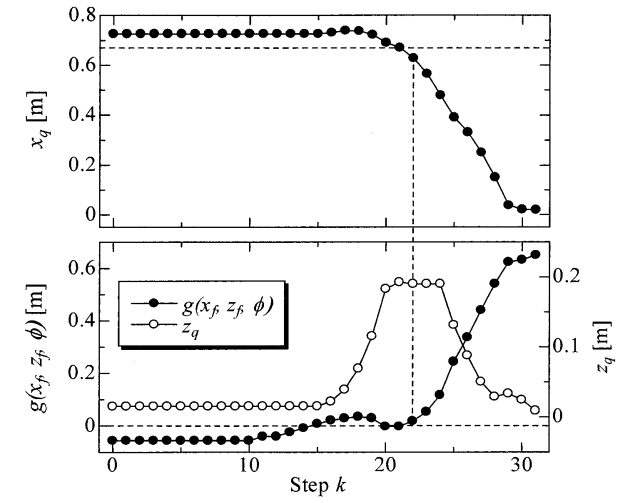

(b-1) Before over (thin line leg)

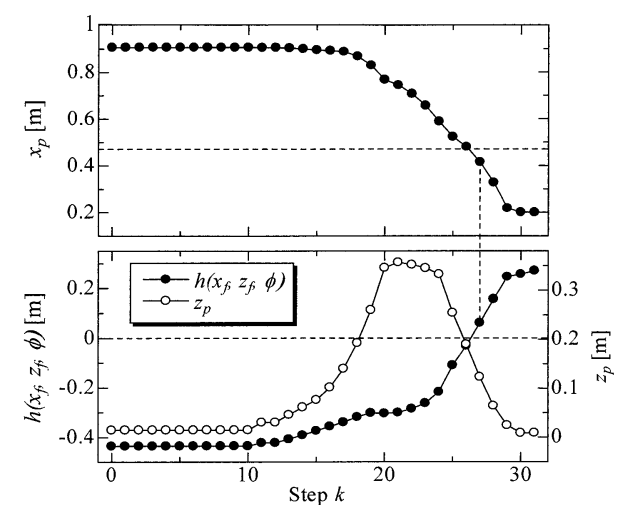

(b-2) After over (thin line leg)

Fig. 5 Results of the stride of biped robot under obstacle constraints

様子を表しており，(b-1),(b-2)はFig. 3 の細線で表され ている脚が遊脚である場合の $(5) \sim(8)$ 式で表現される拘 束条件を表している。また，図中の破線は拘束条件を満 たしているかどうかを示す補助線である。まず(a-1)を見 てみると, $x_{q}$ が障害物の $O$ 点 (Fig. 3 参照) よりも右側 $\left(0.67[\mathrm{~m}]\right.$ 以上) にある場合， $z_{q}>0$ となっていることが わかる。これは拘束条件 (5) 式を表しており，その条件 を満たしていることを示している。また， $x_{q}$ が障害物の $O$ 点 (Fig. 3 参照) よりも左側 $(0.67[\mathrm{~m}]$ 未満) にある場 合, $g\left(x_{f}, z_{f}, \phi\right)>0$ となっていることがわかる.これは 拘束条件 (6) 式を表しており，その条件を満たしている ことを示している。つぎに $(\mathrm{a}-2)$ を見てみると,$x_{p}$ が障

Table 1 Simulation conditions

\begin{tabular}{lrr}
\hline \multicolumn{1}{c}{ Nomenclature } & \multicolumn{1}{c}{ Value } & Unit \\
\hline Simulation step $k:$ & 31 & \\
Initial of $Q=\left(x_{q}, z_{q}\right)$ (swing) & $(1.126,0.033)$ & {$[\mathrm{m}]$} \\
Initial of $P=\left(x_{p}, z_{p}\right)$ (swing) & $(1.282,0.093)$ & {$[\mathrm{m}]$} \\
Initial of $F=\left(x_{f}, z_{f}\right)$ (swing) & $(0.979,0.044)$ & {$[\mathrm{m}]$} \\
Initial of $Q=\left(x_{q}, z_{q}\right)($ lift $)$ & $(0.726,0.015)$ & {$[\mathrm{m}]$} \\
Initial of $P=\left(x_{p}, z_{p}\right)$ (lift) & $(0.906,0.015)$ & {$[\mathrm{m}]$} \\
Initial of $F=\left(x_{f}, z_{f}\right)($ lift $)$ & $(0.816,0.465)$ & {$[\mathrm{m}]$} \\
Obstacle $O=\left(x_{o}, z_{o}\right)$ & $(0.67,0.19)$ & {$[\mathrm{m}]$} \\
Obstacle $R=\left(x_{r}, z_{r}\right)$ & $(0.47,0.19)$ & {$[\mathrm{m}]$} \\
$M_{x f}, M_{z f}, M_{\phi}$ & $0.2,0.2,2.618$ & {$[\mathrm{~m}],[\mathrm{m}],[\mathrm{rad}]$} \\
$W_{x}, W_{z}, W_{\phi}$ & $1.0,1.0,1.0$ & \\
\hline
\end{tabular}

害物の $R$ 点（Fig. 3 参照）よりも左側 $(0.47[\mathrm{~m}]$ 以上か つ0.67[m] 未満) にある場合, $z_{p}>z_{r}\left(z_{r}=0.19[\mathrm{~m}]\right)$ と なっていることがわかる。これは拘束条件 (7) 式を表して 抢り，その条件を满たしていることを示している。また， $x_{p}$ が障害物の $R$ 点（Fig. 3 参照）よりも左側 $(0.47[\mathrm{~m}]$ 未満）にある場合， $h\left(x_{f}, z_{f}, \phi\right)>0$ となっていることが わかる。これは拘束条件 (8) 式を表して抢り，その条件 を満たしていることを示している. (b-1), (b-2) からも Fig. 3 の細線で表されている脚に関して同様に拘束条件 (5)〜(8)式を満たしていることがいえる.

Fig. 6(a-1)〜(a-3) は，Fig. 3において太線で表され ている脚に関する制御入力の差分を示しており，それぞ れ $u_{x f}, u_{z f}, u_{\phi}$ に関するものである. (b-1)〜 (b-3) は Fig. 3 に打いて細線で表されている脚に関する制御入力 の差分を示しており，それぞれ $u_{x f}, u_{z f}, u_{\phi}$ に関するも のである。また，破線はそれぞれ制御入力の差分の上限 抄よび下限を示している。これらを見ると太線・細線で 示された両脚それぞれへの制御入力が $(38)$ 式を基に入力 制限内で生成されていることがわかる。

Fig. 7 は，シミュレーションによって得られたデータ を基にアニメーションを作成し, 実際に二足歩行ロボッ トが障害物を跨ぎ越えている様子を Fig. 1 に示す mode 1〜mode 4 それぞれに示したものである.

これらより，ロボット自身の身体的特徵をも含めた周 


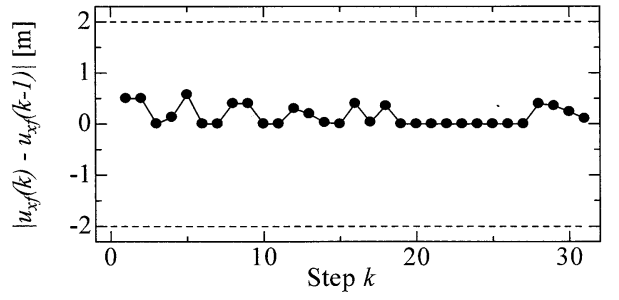

(a-1) Difference of $u_{x f}$ (bold line leg)

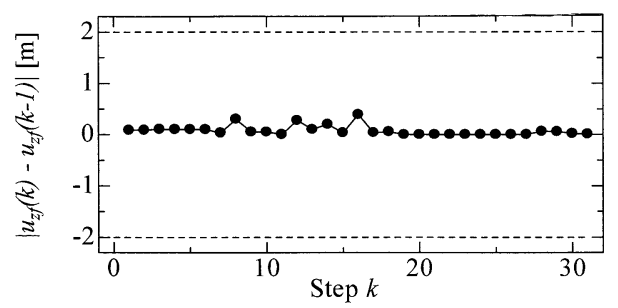

(a-2) Difference of $u_{z f}$ (bold line leg)

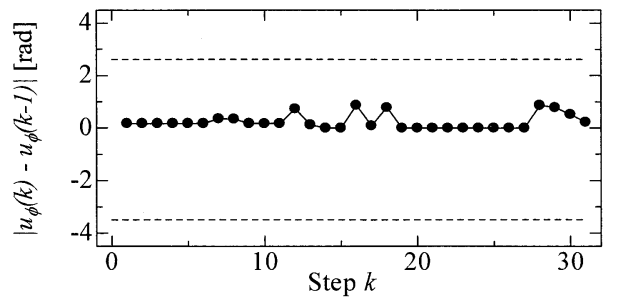

(a-3) Difference of $u_{\phi f}$ (bold line leg)

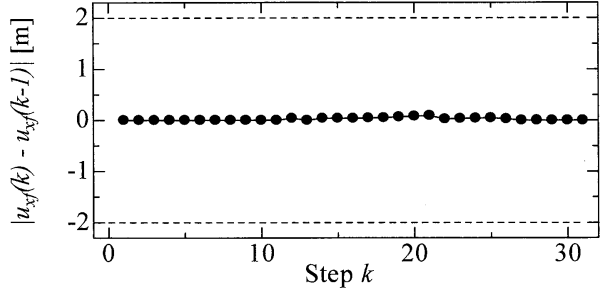

(b-1) Difference of $u_{x f}$ (thin line leg)

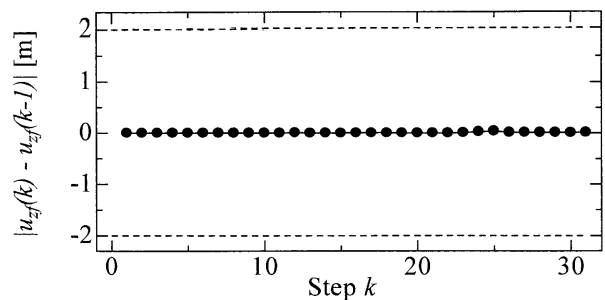

(b-2) Difference of $u_{z f}$ (thin line leg)

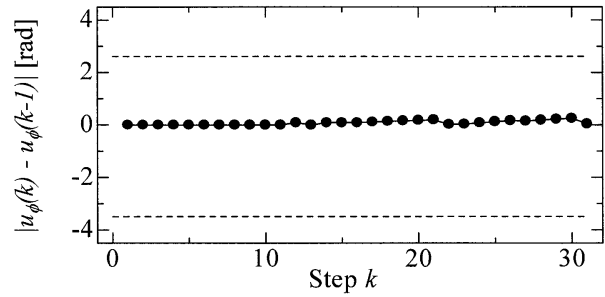

(b-3) Difference of $u_{\phi f}$ (thin line leg)

Fig. 6 Results of the stride of biped robot under input constraints
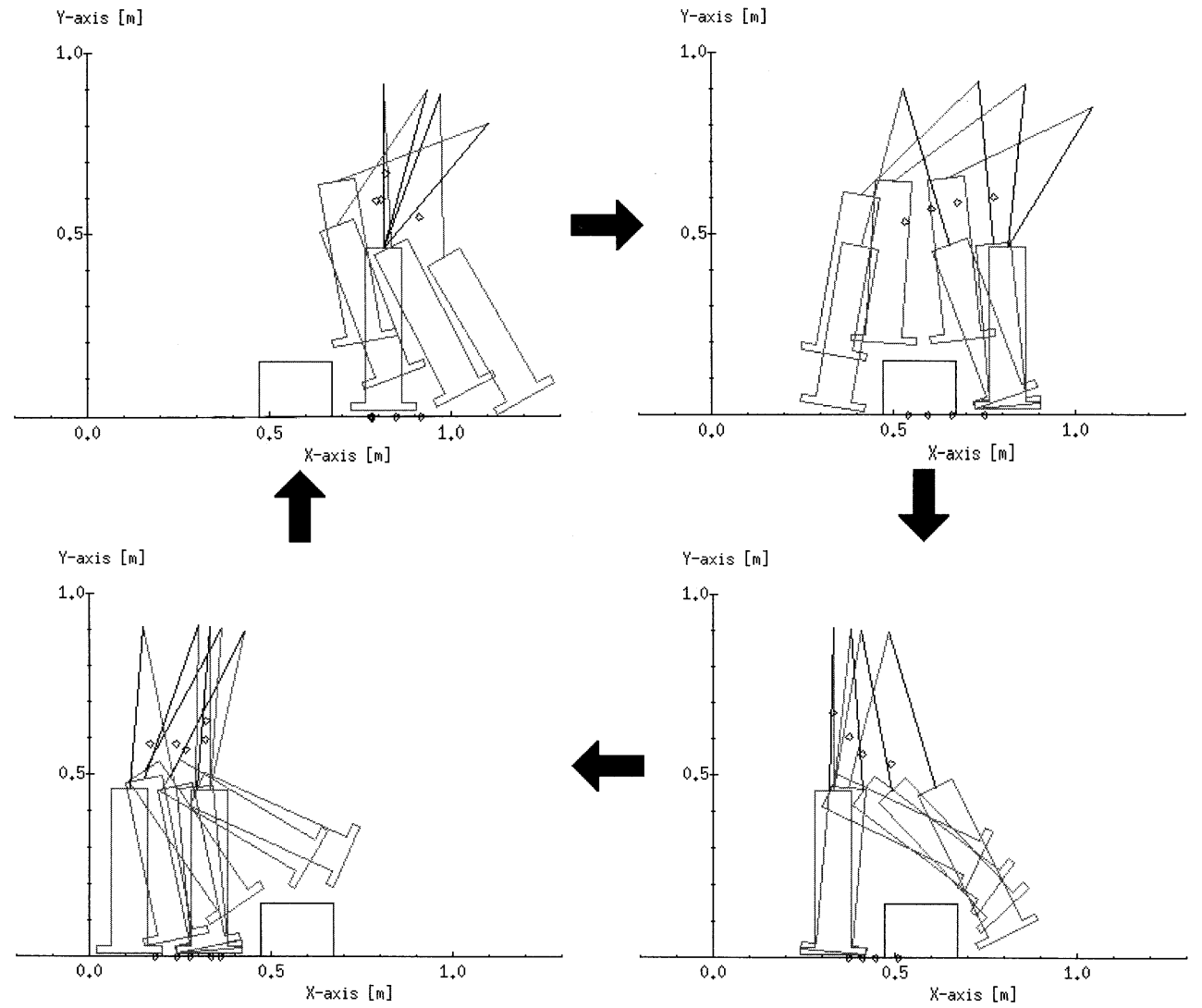

Fig. 7 Results of robot's stride over the rectangle obstacle 
辺環境に対して拘束条件を設け，最適制御手法に基づき 制御入力を生成することで, より人間の行動決定手法に 近い障害物跨ぎ越えを実現できたといえる。

ここで, 本手法のロバスト性に関して述べて扔く. 今回 用いたハイブリッド制御では，ロボットのモデルを基にし た拘束条件が含まれている，モデルにはモデル化誤差が 含まれてるのが一般的であり，実験時にはさらに外乱が混 入することが考えられる. 本論文ではこれらに関する考慮 を行っていないため, 実験を行う場合には悪影響を受ける ことが予想される。しかし，実際に人間が行動する際には 無意識に拘束条件に余裕を持たせていることを考慮する と，今回設定した拘束条件を緩和することでモデル化誤差 や外乱に対するロバスト性が確保できるものと考える.

また，今回はリアルタイムにて最適化計算を行うこ とができないため，フィードフォワード的にシミュレー ションを行ったが, 同様にして実験を行う場合にはモデ ル化誤差によって, 実ロボットの位置と想定している位 置との間にずれが生じることが考えられる。これに関し ては, 数度のサンプリングに一度実ロボットの位置を用 いた最適化計算を行うことで位置ずれを修正することを 考えている。これはサンプリングごとのリアルタイム計 算ではないため，現状で十分可能である.

\section{4. あとがき}

本論文では，二足歩行ロボットが障害物を跨ぎ越える 際の連続事象と離散事象に着目するとともに, 人間の行 動決定手法が周辺環境の拘束条件を考慮している点に着 目した。跨ぎ越えで必要となる拘束条件を導出し，論理 变数を割り当てることで連続事象と離散事象の混在する 系をMLDSで記述した。また, 跨ぎ越えが最短経路と なるよう脚の軌道面積が最小となる評価関数を設定し， 最適制御問題としてシミュレーションを行った。その結 果, すべての拘束条件を満たしつつ, 評価関数を最小と するような制御入力が生成され，人間の行動決定手法に 近い二足歩行ロボットの障害物跨ぎ越えの実現可能性が 確認できた.

\section{謝辞}

本研究を進めるにあたり，数值計算による本手法の検 証に尽力頂いた藤木三朗氏（日本イーライリリー株式会 社）に感謝の意を表す.

\section{参考文献}

[1] M. Vukobratovich, B. Borovac, D.Surla and D. Stokic: Biped Locomotion, Dynamics, Stability, Control and Application, Springer Verlag (1990)

[2] K. Hirai, M. Hirose, Y. Haikawa and T.Takenaka: The development of Honda humanoid robot; Proceedings of the 1998 IEEE International Conference on Robotics 83 Automation, pp. 1321-1326 (1998)
[3] 水戸部, 矢島, 那須 : ゼロモーメント点の操作による歩 行ロボットの制御 ; 日本ロボット学会誌, Vol. 18, No. 3, pp. 359-365 (2000)

[4] Hybrid systems I, II, III, IV, V, Lecture Notes in Computer Science, 736, 999, 1066, 1273, 1567, SpringerVerlag $(1993,1995,1996,1997,1998)$

[5] ハイブリッドシステムーシステム制御への新たな視点総 合特集号; システム/制御/情報, Vol. 46, No. 3, pp. 105$157(2002)$

[6] A. Bemporad and M. Morari: Control of systems integrating logic, dynamics, and constraints; Automatica, Vol. 35, No. 3, pp. 407-427 (1999)

[7] 浅野, 津田, A. Bemporad, M. Morari：ハイブリッド システムの予測制御とそのプロセス制御への適用; システ ム/制御/情報, Vol. 46, No. 3, pp. 110-119 (2002)

[8] K. Hirana, T. Suzuki and S. Okuma: Optimal motion planning for peg-insertion task based on mixed logical dynamical system framework; SICE Annual Conference 2002, pp. 1165-1170 (2002) 